\title{
North Atlantic right whale shift to the Gulf of St. Lawrence in 2015, revealed by long-term passive acoustics
}

\author{
Yvan Simard ${ }^{1,2, *}$, Nathalie Roy ${ }^{1}$, Samuel Giard ${ }^{1}$, Florian Aulanier ${ }^{1}$ \\ ${ }^{1}$ Maurice Lamontagne Institute, Fisheries and Oceans Canada, Mont-Joli, QC G5H 3Z4, Canada \\ ${ }^{2}$ Marine Science Institute, University of Québec at Rimouski, QC G5L 3A1, Canada
}

\begin{abstract}
This paper contributes to documenting a change in the distribution of North Atlantic right whales Eubalaena glacialis (NARWs) that occurred in the 2010s, when the whales largely abandoned their traditional summering grounds in the Gulf of Maine/Bay of Fundy/Scotian shelf. Data from a year-round passive acoustic monitoring (PAM) network in the Gulf of St. Lawrence were exploited to build the time series of NARW incursions into this inland sea of the Northwest Atlantic, from June 2010 to November 2018. NARWs visited the southern Gulf of St. Lawrence every year from June to January, until ice freeze-up. The earliest detections were made at the end of April and the latest in mid-January. Call occurrence peaked between August and the end of October. NARW contact calls were not detected at the most upstream station at Les Escoumins, in the Lower St. Lawrence estuary, or at the northeastern connection of Belle Isle Strait with the Atlantic, which was monitored from November 2010 to November 2011. The mean daily occurrence of NARWs in the feeding grounds off Gaspé quadrupled after 2015 compared to 2011-2014. Long-term continuous PAM data provided invaluable information to document this marine mammal distribution shift.
\end{abstract}

KEY WORDS: Eubalaena glacialis - Ecosystem shift - Gaspé whale feeding ground · Passive acoustic monitoring

\section{INTRODUCTION}

The population of North Atlantic right whales Eubalaena glacialis (NARWs) is recognized as 'endangered' under the Canadian Species at Risk Act, by the Committee on the Status of Endangered Wildlife in Canada, and the International Union for Conservation of Nature (COSEWIC 2013, DFO 2014, Cooke 2018). The estimated population size peaked at $~ 480$ individuals in 2010 and has declined since, with some models estimating as few as 450 in 2016 and 410 in 2017 (Pace et al. 2017, Hayes et al. 2018b, Pettis et al. 2018).

NARWs in the western Atlantic Ocean are distributed mainly along the US continental shelf, between Florida and the northern Gulf of Maine, extending

${ }^{*}$ Corresponding author: yvan.simard@dfo-mpo.gc.ca to the eastern Canadian shelf including the Bay of Fundy and the Western Scotian shelf. A notable fraction of the population extends from the midAtlantic to southern Greenland (Kraus \& Rolland 2007b, Davis et al. 2017). The seasonal migration between northern feeding grounds, mating grounds and southern calving grounds off Florida and Georgia involves a part of the population, while another part overwinters in other areas of the wider distribution (Morano et al. 2012, Cole et al. 2013, Bort et al. 2015, Davis et al. 2017). In late fall to early winter, pregnant females migrate to the waters of the southern USA, where they give birth (Kraus et al. 1986). The central Gulf of Maine is one area where mating occurs in winter (Cole et al. 2013). Traditional

(C) The authors 2019. Open Access under Creative Commons by Attribution Licence. Use, distribution and reproduction are unrestricted. Authors and original publication must be credited. 
Northwest Atlantic feeding grounds were distributed from Cape Cod to the Scotian Shelf, notably the Bay of Fundy (Wishner et al. 1995, Baumgartner et al. 2003a,b, 2017, Baumgartner \& Mate 2003, Davis et al. 2017). However, part of the population is likely exploiting other grounds, which largely remain to be discovered and documented (Kraus \& Rolland 2007a, Davis et al. 2017).

An overview of the spatio-temporal distribution of NARWs in the western North Atlantic from analyses of passive acoustic monitoring (PAM) datasets collected between 2004 and 2014 evidenced a decrease in detections in the northern Gulf of Maine after 2010, with a simultaneous increased presence in the mid-Atlantic (Davis et al. 2017). Further north, in the Gulf of St. Lawrence, occasional NARW sightings were reported (DFO 2014). This drastically changed recently, when a large number of NARWs were observed in the southern Gulf of St. Lawrence, where 12 individuals were found dead and another 5 were entangled in 2017, which triggered protection measures from management authorities (DFO 2018, MeyerGutbrod et al. 2018, Pettis et al. 2018). The present paper is an effort to better document this recent change in NARW use of the Gulf of St. Lawrence, by analysing the time and space pattern of NARW upcalls recorded between 2010 and 2018 with a network of 8 PAM stations distributed in the Estuary and Gulf of St. Lawrence.

\section{MATERIALS AND METHODS}

\subsection{NARW up-call}

NARWs produce several types of sounds, but the call that can identify the species is a stereotyped lowfrequency upsweep produced by both sexes, known as an up-call or a contact call, which lasts about $1 \mathrm{~s}$ with frequency rising between approximately 100 and $300 \mathrm{~Hz}$, although considerable variability is observable (Clark 1982, Parks \& Tyack 2005, Parks et al. 2009, 2011, Trygonis et al. 2013). Call rates also vary over time and space (Matthews et al. 2001, Van Parijs et al. 2009, Parks et al. 2011). Calls are common when the whales are in surface active groups, rarer when feeding (possibly in response to calling limitation at daytime prey depth), and long periods of silence are common. Call depths of tagged NARWs were generally observed in the upper water column above $10 \mathrm{~m}$, between dives. Some calls were noted at greater depths, including extremes down to $\sim 120 \mathrm{~m}$ (Parks et al. 2011). The NARW up-call source level
(SL) was estimated at $165 \pm 3.5(\mathrm{SD}, \mathrm{n}=353) \mathrm{dB}$ re $1 \mu \mathrm{Pa}_{\mathrm{rms}} @ 1 \mathrm{~m}$ (Clark et al. 2011).

\subsection{PAM observatory}

The PAM observatory included 8 stations located in the Lower Estuary and Gulf of St. Lawrence (Fig. 1). Two stations were located at the 2 openings to the Atlantic, namely Cabot and Belle Isle straits; 1 in the most upstream baleen whale feeding ground (Simard \& Lavoie 1999, Simard 2009), at Les Escoumins; 1 about $75 \mathrm{~km}$ further downstream called 'Lower Estuary'; 2 positioned within the basin east of the Gaspé peninsula ('Cap d'Espoir' and 'Percé'); 1 in an extension of the same topographic basin northeast of New Brunswick called 'Shédiac', at the head of the similarly named underwater valley; and 1 station, named 'Old Harry', was located along an expected 2-way migration path between the western Gulf feeding areas and Cabot Strait. The recordings covered an 8 yr period, from June 2010 to November 2018, with series lengths varying between stations from 1 to 7.8 yr (Fig. 2).

At each station, an AURAL autonomous underwater recorder (AURAL-M2, Multi-Electronique; www.multi-electronique.com/aural.html) was deployed $\sim 50 \mathrm{~m}$ off the bottom following a typical Itype oceanographic mooring, comprising an anchor, an acoustic release, the instrument, and low-drag streamlined sub-surface floats (cf. Simard \& Roy 2008). The AURALs sampled the $16 \mathrm{~dB}$ pre-amplified acoustic signal with 16-bit resolution and sampling rates between 8192 and 32768 samples $\mathrm{s}^{-1}$ for 15 or $30 \mathrm{~min}^{-1}$ depending on the year. The receiving sensitivity of the HTI 96-MIN (High Tech) hydrophone in the AURAL was $-164 \pm 1 \mathrm{~dB}$ re $1 \mathrm{~V} \mu \mathrm{Pa}^{-1}$ over the $<4 \mathrm{kHz}$ bandwidth used here, as confirmed by calibrations made at the calibration facility of Defence Research and Development Canada - Atlantic (Dartmouth, Nova Scotia).

\subsection{NARW up-call detector}

Several algorithms have been proposed for automatic detection of NARW contact calls (Gillespie 2004, Mellinger 2004, Urazghildiiev \& Clark 2006, 2007, Urazghildiiev et al. 2008, Baumgartner \& Mussoline 2011). The present NARW contact call (Fig. 3a,c) detector draws from Mellinger (2004) and is based on spectrogram cross-coincidence with a synthetic upsweep call template (Mouy et al. 2009). 


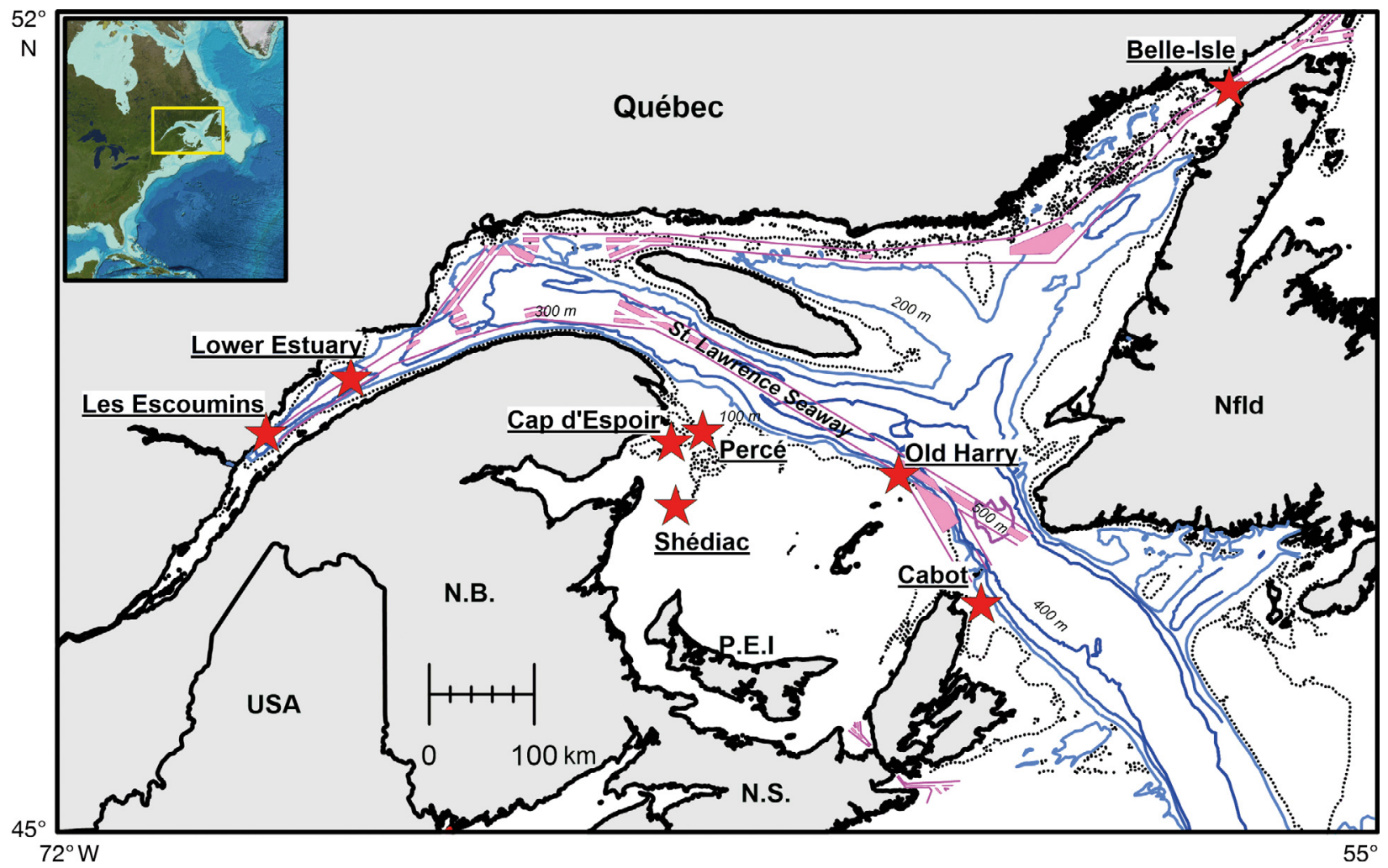

Fig. 1. Bathymetric map of the Gulf of St. Lawrence showing the traffic lanes (magenta lines) and the location of the 8 stations (red stars) of the passive acoustic monitoring observatory. The inset was reproduced from the GEBCO world map 2014 (www.gebco.net)

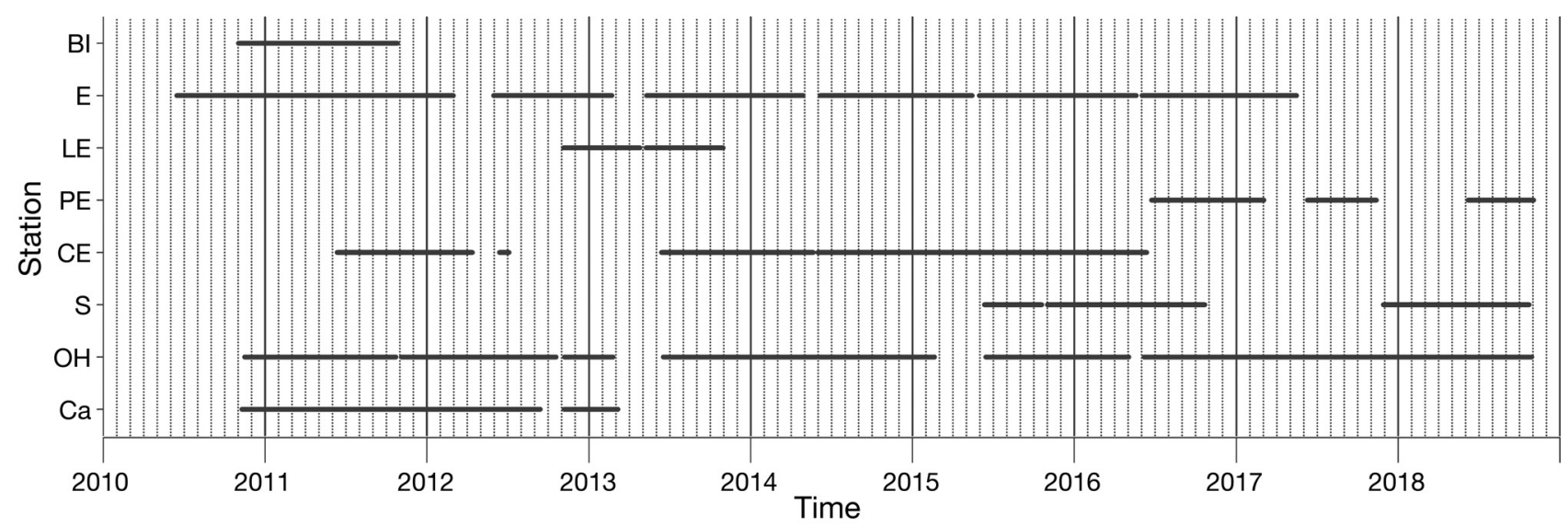

Fig. 2. Recording schedule at the 8 stations shown in Fig. 1, sorted from north to south. BI: Belle Isle; E: Escoumins; LE: Lower Estuary; PE: Percé; CE: Cap d'Espoir; S: Shédiac; H: Old Harry; Ca: Cabot Strait

The signal processing steps (Fig. 4) include downsampling to 1000 samples $\mathrm{s}^{-1}$, spectrogram computation with a 256-point discrete Fourier transform, a Hann window and $87 \%$ overlap, corresponding to a frequency resolution of $3.9 \mathrm{~Hz}$ and a time resolution of $32 \mathrm{~ms}$. The signal to noise ratio (SNR) is enhanced by noise reduction before computing the detection function. The upsweep call is modelled as a $1 \mathrm{~s}$ frequency sweep kernel from 100 to $200 \mathrm{~Hz}$ with a bandwidth of $20 \mathrm{~Hz}$, which accounts for the upsweep rate variability (e.g. Fig. 3). The resulting detections were manually checked by an expert and labelled as 'true' or 'false' using the adjacent call pattern in $\mathrm{a} \sim 1$ min window to discriminate between 

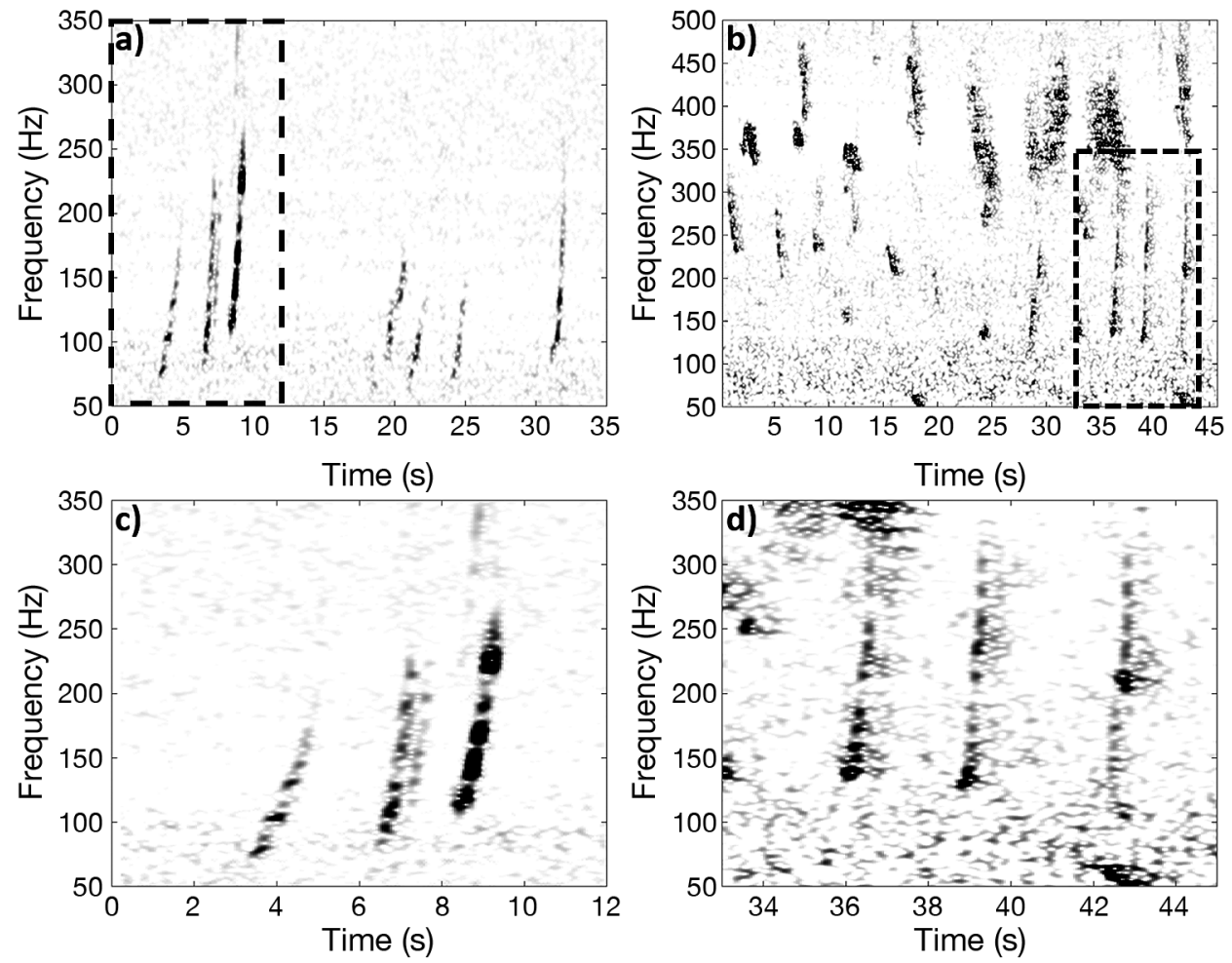

Fig. 3. Examples of $(\mathrm{a}, \mathrm{c})$ North Atlantic right whale contact calls and $(\mathrm{b}, \mathrm{d})$ confounding humpback whale upsweeps. The dashed areas in (a) and (b) are expanded in (c) and (d), respectively. Spectrogram resolution of $0.2 \mathrm{~Hz}$ and $0.05 \mathrm{~s}$

NARW calls and other sources such as humpback whales (Fig. 3b,d) (Clark et al. 2007, Mussoline et al. 2012). False detections were excluded from further analysis.

The detection algorithm was tuned to favour exactness (i.e. precision) while maintaining a high level of completeness (i.e. recall) (Perry et al. 1955). Its performance was estimated from a representative subset of files (with low to high numbers of detections), taken from the Cap d'Espoir, Percé and Shédiac stations, where most detections were found. The precision index (i.e. percentage of properly classified true detections) before excluding false detections was $91 \%$. This precision index was brought to $100 \%$ with the validation of all detections by an expert. The recall index (i.e. percentage of detected true up-calls from all those present in the recordings) was estimated at $51 \%$. The recall index increases with SNR and reaches $62 \%$ for SNR $>5 \mathrm{~dB}$. Missed detections were due to low SNRs and variability of the upsweep calls, originating from both the sources and propagation effects. The algorithm performance did not change as a function of call density, as demonstrated by the strong linear relationship between the number of true detections per file vs. the number of groundtruthed calls $\left(r^{2}=0.92\right)$.

\subsection{NARW time pattern}

NARW presence and occurrence indices were computed from validated NARW up-call detections for 2 time steps: hourly and daily. The hourly detection density is the number of up-call detections $\mathrm{h}^{-1}$ computed for each duty cycle time (i.e. 0.25 or $0.50 \mathrm{~h}$ ). Daily detection hours is the number of hours in a day in which 1 or more up-calls were detected. The binary daily presence index refers to the absence or presence of at least 1 up-call in a day. The different duty times are not involved in the computation of these latter 2 occurrence metrics. To generate a time series of NARW presence and occurrence for the whole basin off Gaspé, the data from 3 stations (Cap d'Espoir, Percé and Shédiac) were combined. The daily NARW up-call occurrence index for the basin was given by the maximum daily detection hours observed among the 3 stations. Daily presence in the basin was triggered by at least 1 up-call detected at any station. To determine the overall pattern of NARW presence and occurrences in the basin over the annual cycles between 2011 to 2018, the metrics for each calendar day were averaged over the years. 


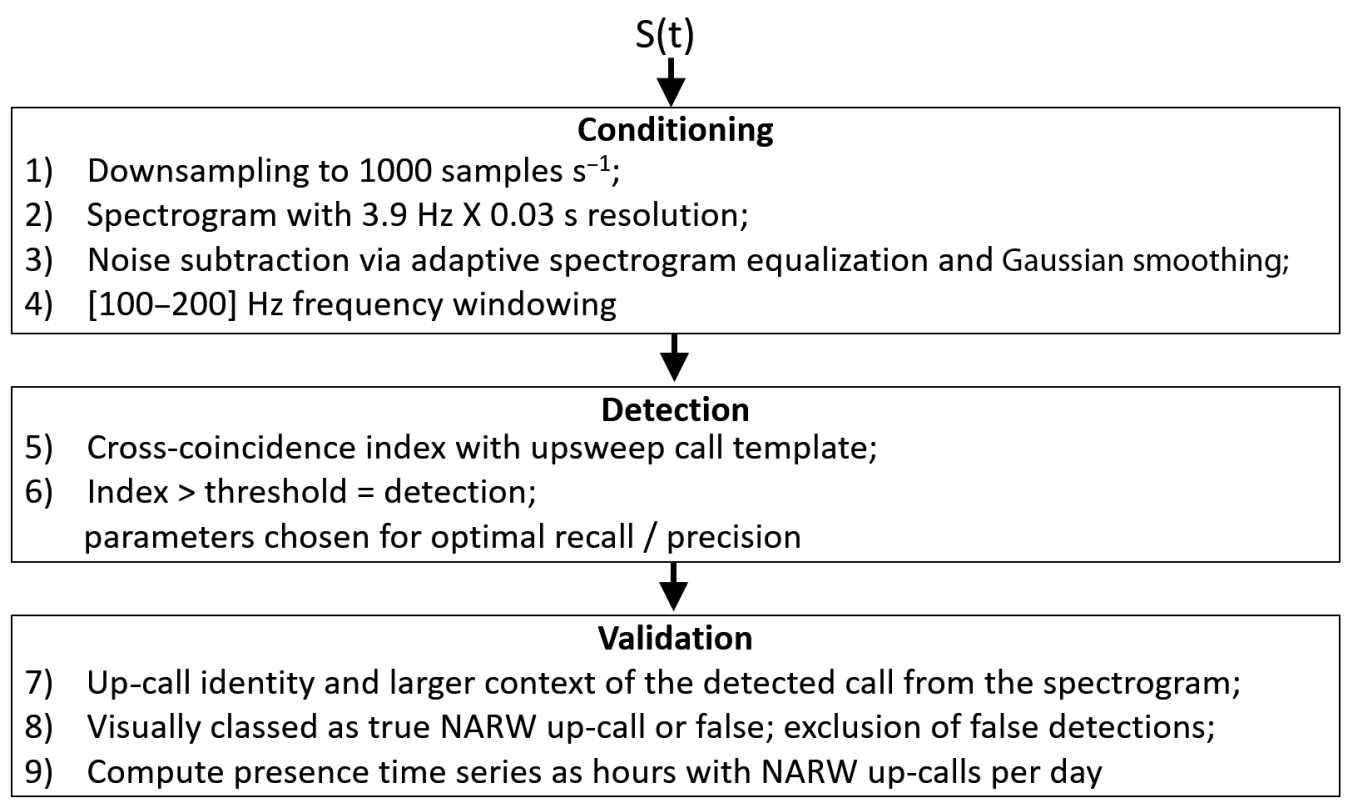

Fig. 4. Signal processing scheme of the North Atlantic right whale (NARW) contact call detector. S(t): recorded acoustic data

The existence of calling rhythms along the time series at a station was first examined by mapping the hourly density of NARW up-call detections as a function of the hour of the day. The sunset and sunrise times from a NOAA solar calculator (www.esrl.noaa.gov/ gmd/grad/solcalc/calcdetails.html) were superimposed to track eventual twilight changes in up-call density. The presence of lines of high up-call density on this map reveals a departure from the null hypothesis of random distribution of up-call densities over the time of day. The $24 \mathrm{~h}$ anomaly (i.e. hourly call density minus the mean hourly density of the day) was then computed following Mussoline et al. (2012) and tested for significant differences between hours of the day.

Statistical tests were performed with JMP ver. 13.2.1 (SAS Institute).

\subsection{Detection ranges and areas}

The detection ranges at the PAM stations where NARW up-calls were recorded were estimated from the call source level (SL), transmission loss (TL) and the probability distribution function of the measured noise level (NL) in the up-call band at the 3-dimensional locations of the PAM recorders during a complete annual cycle. The NARW up-call SL was set to $165 \mathrm{~dB}$ re $1 \mu \mathrm{Pa}_{\mathrm{rms}} @ 1 \mathrm{~m}$ (Clark et al. 2011, SD = 3.5 $\mathrm{dB}, \mathrm{n}=353$ ). The calling depth was set to $15 \mathrm{~m}$ following D-tag measurements showing that most calls are produced in the upper water column (Parks et al.
2011). TL at $100 \mathrm{~Hz}$ between the source and the recorder were computed for a $200 \times 200 \mathrm{~km}$ grid around the station, with $2 \times 2 \mathrm{~km}$ resolution. A parabolic equation (PE) propagation model (Collins 1993, OALIB 2016) was configured with typical summer water mass characteristics (corresponding to the season of NARW presence), from the outputs of an operational 3-dimensional circulation model of the Estuary and Gulf of St. Lawrence for 1 July 2013 (Senneville \& Lefaivre 2015), and bottom geoacoustic properties from Loring \& Nota (1973) and Jensen et al. (2011) (Aulanier et al. 2016a,b). The modelled received levels $\left(\mathrm{RL}_{\text {call }}\right)$ at the stations were compared to the corresponding NL cumulative probability (cumulative density function [cdf]) over the annual cycle at the stations, to get the probability of detecting a source located at the modelled node of the TL grid. Assuming a conservative detection threshold equal to an SNR of 0 $\mathrm{dB}$, the detection probability for the given node is the cdf (NL) value corresponding to the $\mathrm{RL}_{\text {call }}$ (i.e. cdf ([NL $\left.\left.\left.=\mathrm{RL}_{\text {call }}\right]\right)\right)$. The detection area $\left(\mathrm{A}_{\mathrm{p}(\mathrm{det})}\right)$ that exceeds a given threshold $(s)$ of detection probability $(\mathrm{p}(\mathrm{det})>s$ ) at the station is given by the sum of the areas $([2 \times 2]$ $\mathrm{km}^{2}$ ) of all corresponding source nodes. When $s=0.5$, we have the median detection area, where the detection probability exceeds $50 \%$. The equivalent detection range is estimated as $\mathrm{r}=\sqrt{\mathrm{A}_{\mathrm{p}(\operatorname{det})} / \pi}$. The relative median detection areas, $\mathrm{RA}_{\mathrm{p} \text { (det) }}$ (i.e. the ratio of median detection area at the station to the smallest median detection area of all stations), were computed for each PAM station. 


\section{RESULTS}

\subsection{NARW time pattern}

NARW contact call detections were present from the end of April to mid-January at 4 of the stations: Percé, Cap d'Espoir, Shédiac and Old Harry (Figs. 1, $5,6)$. They were not detected at the other stations, including Cabot Strait, which was on duty for 2 yr from November 2010, and Belle Isle Strait and the middle of the Lower Estuary, which were both monitored for 1 yr each (Fig. 2). NARW up-calls were not detected at the most upstream station, Les Escoumins, which was monitored for $6.6 \mathrm{yr}$. The up-call daily presence at the Old Harry station was sporadic and low throughout the 2011-2018 time series (average of yearly mean daily presence from June to January $=3.2 \pm 1.9 \%$ ), including no detections in 2013 (Fig. 5).

The period when most detections occurred varied from year to year (Fig. 6). In 2017, it was delayed by 2 mo based on the Percé station recordings, compared to 2015, 2016 and 2018. The occurrence exhibited daily variations superimposed on consistent weekly or longer trends. On average, the occurrence increased from June to the beginning of September before decreasing with recurrent pulses until January.

At the Cap d'Espoir station, the occurrence and continuity of detections between June and January significantly increased from a mean of 0.18 daily detection hours (or daily presence of $9 \%$ ) in 2011 to a mean of 2.08 daily detection hours (or daily presence of $53 \%$ ) in 2015 (nonparametric Dunn tests, p < 0.01). This high occurrence continued in the following years at the monitored Percé and Shédiac stations (Figs. 5 \& 6). In 2015, the consolidated time series for the basin off Gaspé showed a 4 -fold increase in the proportion of days with presence, accompanied by an order of magnitude increase in the number of detections or hours with up-calls per day (Tables 1 \& 2, Fig. 7). The difference in occurrence and presence before and after 2015 was significant (nonparametric Dunn test $\mathrm{p}<0.01$ ) for all months, except December, where the number of zeros in 2011-2014 was too high to perform the rank test.

\subsection{Diel patterns in NARW up-calls}

The NARW contact calls were evenly detected throughout the diel cycle with no marked diel rhythm
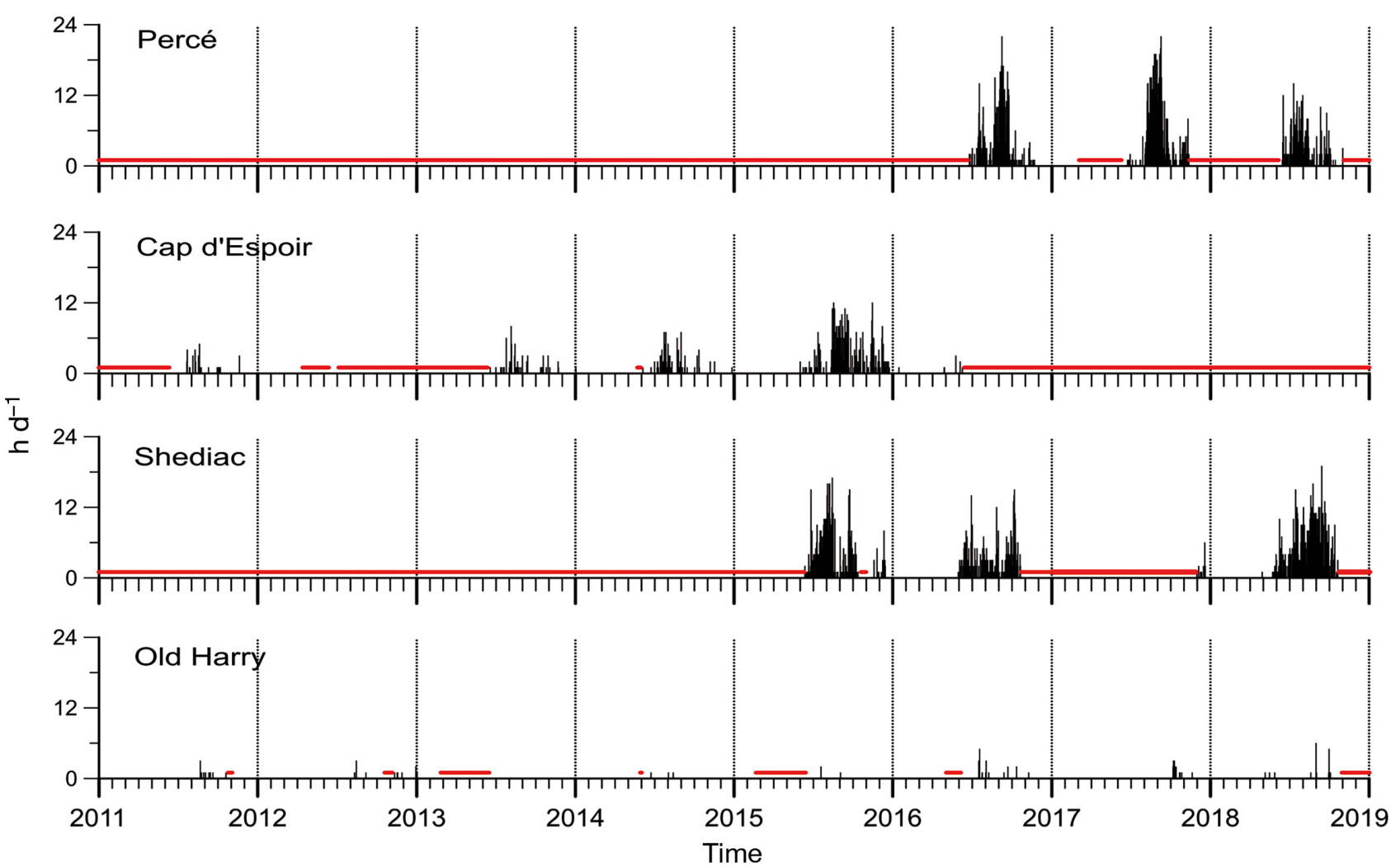

Fig. 5. Time series of North Atlantic right whale (NARW) daily detection hours at the 4 passive acoustic monitoring stations where NARW contact calls were detected. Red lines indicate non-recording periods 
(Fig. 8). The hourly detection anomaly was centered at zero for most hours of the day, with slight, but significant ( $t$-test for zero mean, $\mathrm{p}<0.01$ ) positive deviations $\left(<1.1\right.$ or 0.5 detections $\mathrm{h}^{-1}$ for Percé and Shédiac, respectively) around sunset (19:00 and 20:00 h), and negative deviations at 12:00, 14:00 and 15:00 h for Shédiac (Fig. 8, right panels).

\subsection{Detection ranges and areas}

The median detection areas were smallest at Old Harry and Cabot stations, along the Laurentian Channel where the St. Lawrence Seaway main shipping route is located (Simard et al. 2014) (Figs. 1 \& 9, Table 3). They were 10 times larger at the 3 other sta-

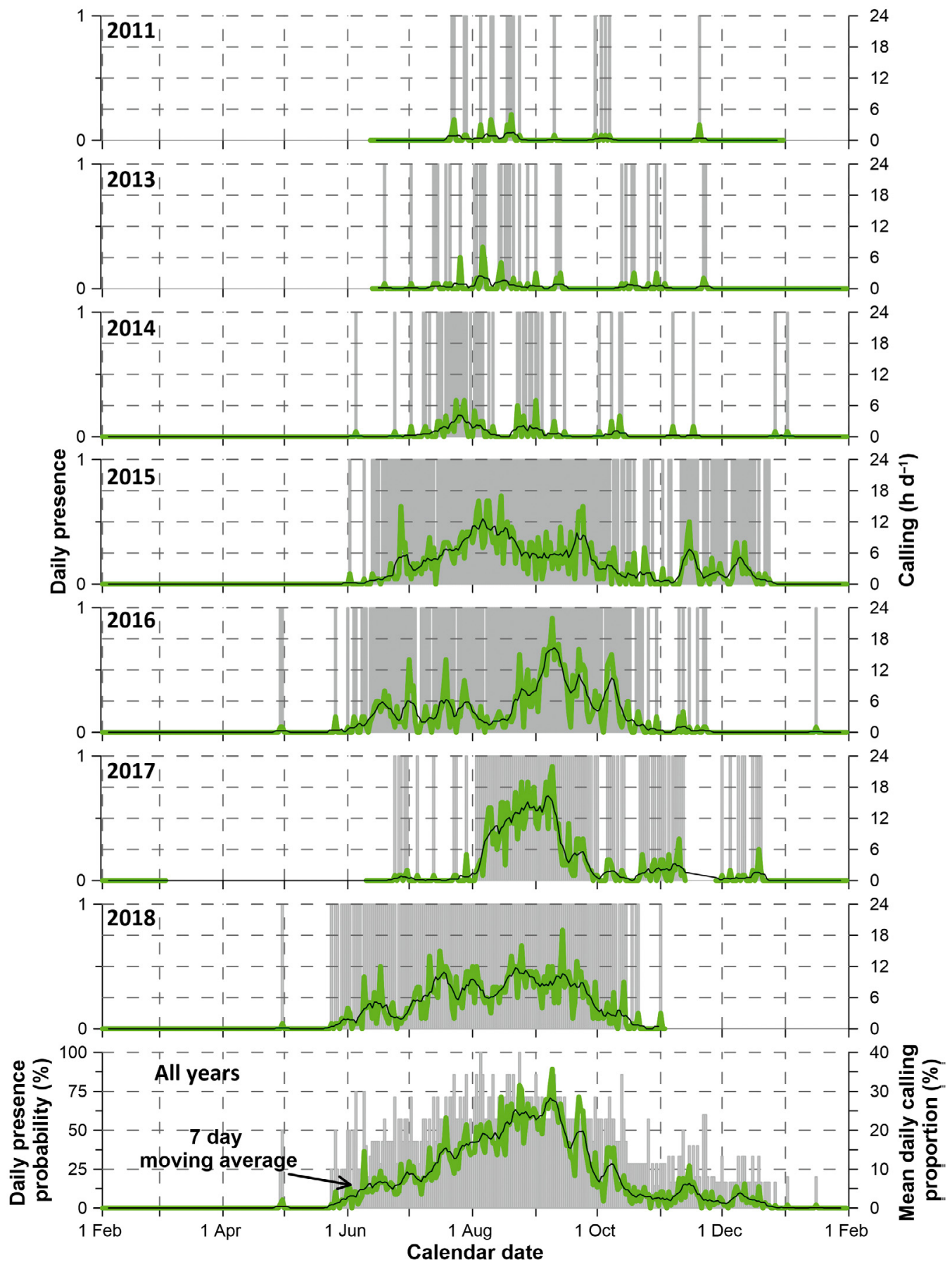

Fig. 6. Daily presence (shaded) and occurrence (lines) of North Atlantic right whale contact calls in the area monitored by the 3 passive acoustic monitoring stations in the basin off Gaspé. Thin line is the weekly average. Green lines indicate recording periods 
Table 1. Occurrence of North Atlantic right whale up-calls between 1 February and 31 January (3 November for 2018), from the consolidated time series in Fig. 6. Values are given as means \pm SD

\begin{tabular}{|lccccccc|}
\hline & 2011 & 2013 & 2014 & 2015 & 2016 & 2017 & 2018 \\
\hline $\begin{array}{l}\text { Presence } \\
(\% \text { of observed days })\end{array}$ & 7.7 & 9.6 & 12.9 & 46.3 & 39.1 & 40.4 & 52.2 \\
$\begin{array}{l}\text { Occurrence } \\
\left(\mathrm{h} \mathrm{d}^{-1}\right)\end{array}$ & $0.15 \pm 0.64$ & $0.19 \pm 0.78$ & $0.32 \pm 1.04$ & $2.46 \pm 3.74$ & $2.22 \pm 4.00$ & $2.57 \pm 4.79$ & $3.32 \pm 4.29$ \\
$\begin{array}{l}\text { Detections } \\
\left.(\text { det. d })^{-1}\right)\end{array}$ & $0.7 \pm 3.9$ & $0.4 \pm 2.1$ & $0.8 \pm 3.4$ & $8.6 \pm 17.0$ & $11.3 \pm 31.9$ & $10.0 \pm 27.8$ & $7.1 \pm 9.6$ \\
\hline
\end{tabular}

Table 2. Occurrence of North Atlantic right whale up-calls between 1 June and 31 December (3 November for 2018). Values are given as means $\pm \mathrm{SD}$

\begin{tabular}{|lccccccc|}
\hline & 2011 & 2013 & 2014 & 2015 & 2016 & 2017 & 2018 \\
\hline $\begin{array}{l}\text { Presence } \\
(\% \text { of observed days })\end{array}$ & 8.9 & 17.1 & 22.0 & 78.5 & 65.0 & 53.9 & 87.8 \\
$\begin{array}{l}\text { Occurrence } \\
\left(\mathrm{h} \mathrm{d}^{-1}\right)\end{array}$ & $0.18 \pm 0.69$ & $0.38 \pm 1.12$ & $0.55 \pm 1.31$ & $4.19 \pm 4.07$ & $3.76 \pm 4.65$ & $3.43 \pm 5.27$ & $5.81 \pm 4.26$ \\
$\begin{array}{l}\text { Detections } \\
(\text { det. d }\end{array}$ & $0.8 \pm 4.2$ & $0.9 \pm 3.1$ & $1.4 \pm 4.4$ & $14.7 \pm 20.1$ & $19.4 \pm 39.9$ & $15.1 \pm 33.1$ & $12.4 \pm 9.9$ \\
\hline
\end{tabular}

tions in the basin off Gaspé, where they exceeded $3000 \mathrm{~km}^{2}$. The Percé and Cap d'Espoir detection areas largely overlapped (by 53\% for the median detection area), with the latter station better monitoring the entrance of the Baie des Chaleurs (Fig. 9b,d). The Shédiac detection area was shifted south but still largely overlapped for distant calls whose detection probability was $<50 \%$ (not shown). Its median detection area still intersected those of Cap d'Espoir and Percé, by 3 and $2 \%$, respectively (Fig. 9b,d,f).

\section{DISCUSSION}

\subsection{NARW time pattern in relation to adjacent regions}

The analysis of a decadal series of PAM recordings from 2004-2014 in NARW habitat in the Northwest Atlantic, from Florida to Davis Strait, revealed a summer-fall decrease in NARW up-call detections in southern grounds, reflecting a seasonal movement of animals towards northern feeding grounds (Davis et al. 2017). In August and September, there were no detections south of Cape Cod while they were present further north. Occurrence on the Scotian Shelf peaked between September and December. In the adjacent Gulf of Maine-Fundy region, the occurrence peaked before and after the Scotian Shelf, in agreement with a north-south seasonal migration. Comparisons of pre- and post-2010 periods also showed a notable reduction of up-call occurrence in Gulf of Maine-Fundy-Scotian Shelf after 2010, accompanied by an increase in regions south of Cape Cod (Davis et al. 2017).

The present PAM series analysis overlaps with the period of the above study, for 2011-2014, when upcall detections decreased in adjacent regions of the Scotian Shelf-Fundy-Gulf of Maine. During that period, the presence and total occurrences of up-calls increased in the southern Gulf of St. Lawrence from June to January, indicating that some NARWs were pushing north, while a part of the population was retreating south (Davis et al. 2017). However, this northern push shifted in 2015, when the up-call detections in the southern Gulf of St. Lawrence jumped and became abundant and quasi-continuous from June to January. A delayed occurrence in the southwestern Gulf of St. Lawrence was manifest in 2017, when 12 animals were found dead in the area. The removal of these early migrating animals may explain the low early call detections in that year. Yet, this may also simply reflect the natural variability in the time-space use of the Gulf.

The all-years average call occurrence continually increased from early June to mid-September, and then decreased. If this reflects the average NARW density, then the northward migration of animals 

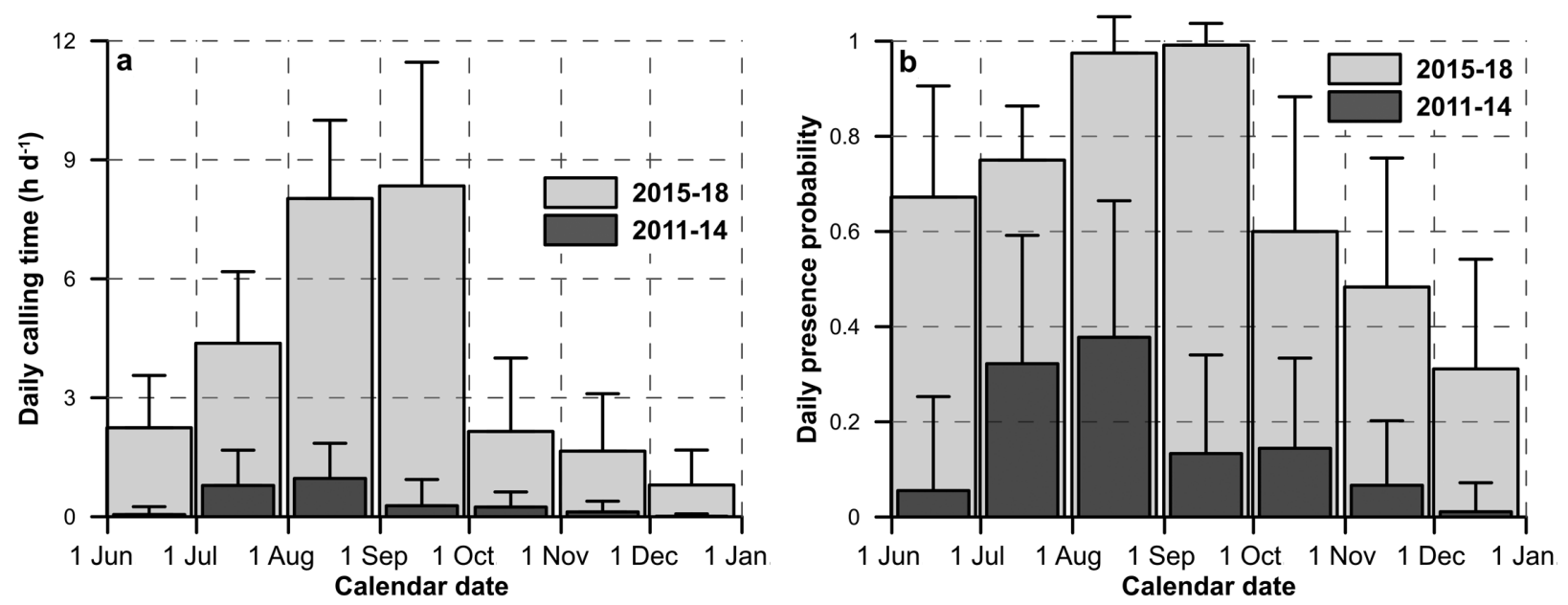

Fig. 7. Mean (a) daily occurrence or (b) presence of North Atlantic right whale contact calls in the area monitored by the 3 passive acoustic monitoring stations off Gaspé peninsula, separately for 2011-2014 and 2015-2018. The error bars are SD
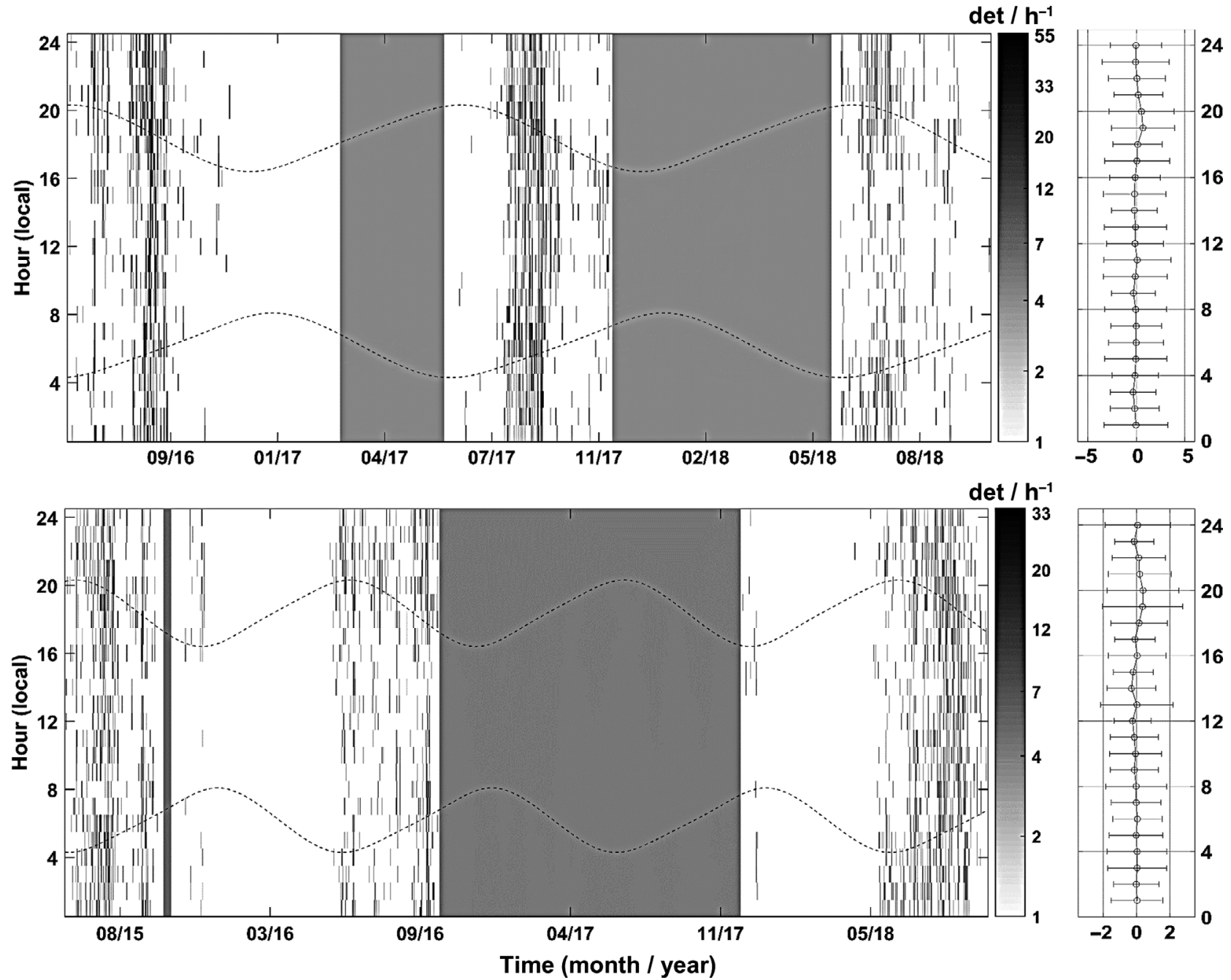

Fig. 8. Hourly density (up-call $\mathrm{h}^{-1}$ ) of North Atlantic right whale contact calls as a function of the hour of the day and time of year (left panels), and hourly mean anomaly \pm SD as function of the hour of day (right panels), for Percé (top) and Shédiac (bottom) stations. The dashed lines indicate sunset and sunrise times. Shaded areas are periods without recordings 

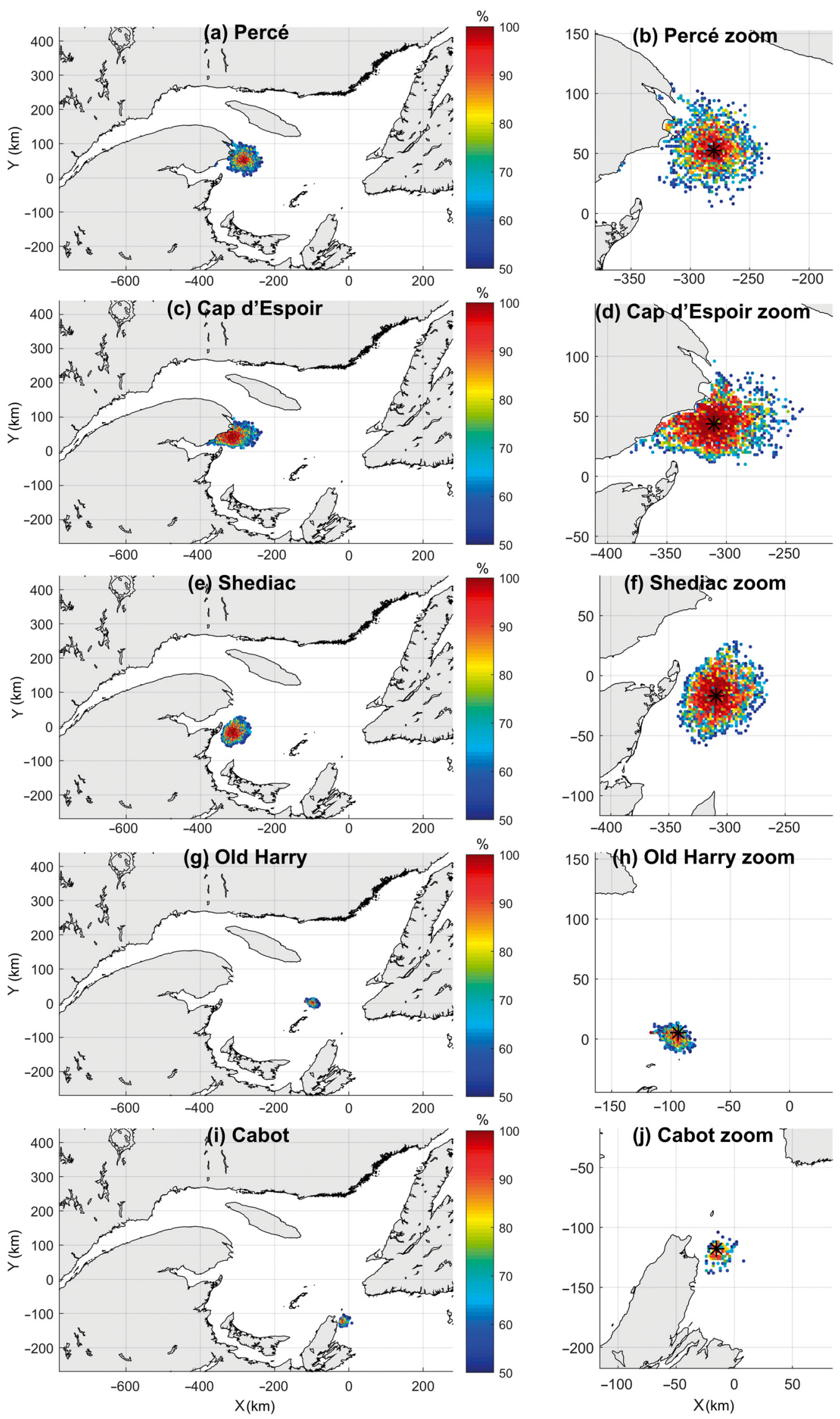

Fig. 9. Probability (>50\%) of detecting a North Atlantic right whale contact call around each of 5 passive acoustic monitoring stations in the Southern Gulf of St. Lawrence from the cumulative density function of the ocean noise at the 3-dimensional locations of the recorders and the transmission losses from parabolic equation acoustic modelling for sources located at $2 \times 2 \mathrm{~km}$ nodes of a $200 \times 200 \mathrm{~km}$ grid around the stations 
Table 3. Median detection areas of North Atlantic right whale up-calls at the passive acoustic monitoring stations. A: area; RA: relative area. See Section 2.5 for detailed definitions

\begin{tabular}{|lccc|}
\hline Station & $\begin{array}{c}\text { Detection area } \\
\left(\mathrm{km}^{2}\right) \\
\left(\mathrm{A}_{\mathrm{p}(\mathrm{det})}>50 \%\right)\end{array}$ & $\begin{array}{c}\text { Relative } \\
\text { detection area } \\
\left(\mathrm{RA} \mathrm{A}_{\mathrm{p}(\mathrm{det})>50 \%)}\right.\end{array}$ & $\begin{array}{c}\text { Equivalent } \\
\text { detection } \\
\text { radius }(\mathrm{km})\end{array}$ \\
\hline Percé & 3216 & 9.8 & 32 \\
Cap d'Espoir & 3840 & 11.7 & 35 \\
Shédiac & 3248 & 9.9 & 32 \\
Old Harry & 329 & 1.0 & 10 \\
Cabot & 332 & 1.0 & 10 \\
\hline
\end{tabular}

from the south is primarily active until $\sim$ mid-September before right whales begin to retreat.

The recent increased NARW presence in the Gulf of St. Lawrence appears to be connected with the changes observed in southern PAM series, especially the reduction of the occurrence in their traditional feeding ground between Cape Cod and the Eastern Scotian Shelf. This reduction has been attributed to changes in ocean conditions affecting their main prey in this region (Greene et al. 2013, Meyer-Gutbrod et al. 2015, Greene 2016, Grieve et al. 2017, Hayes et al. 2018a, Meyer-Gutbrod \& Greene 2018). The coincident decrease in NARW population growth rate might be linked to the same ocean process because of the strong link between birth rates and prey availability (Meyer-Gutbrod \& Greene 2018). Does the Gulf of St. Lawrence feeding ground offer a compensation alternative to the depleted traditional southern feeding ground? Further research on the concomitant monitoring time-series of the zooplankton prey should help to answer this question, and predict the durability of this distribution change. How the occupation of this northern feeding ground shifted in 2015 from a few vagrant individuals to a significantly larger proportion of the NARW population is another question worth addressing to help predict eventual further distribution changes.

\subsection{NARW space pattern}

The NARW contact call is a relatively faint low-frequency call ( 165 dB re $1 \mu \mathrm{Pa} @ 1$ m; Clark et al. 2011) compared to the strong infrasounds of fin and blue whales ( 190 dB re $1 \mu \mathrm{Pa} @ 1$ m; Širovi et al. 2007). The peak frequency is below $200 \mathrm{~Hz}$ (Parks \& Tyack 2005, Clark et al. 2011), which is within the frequency band affected by significant low-frequency ship noise (Simard et al. 2016). The probability of detecting NARW contact calls above background ambient noise is therefore reduced in areas exposed to major shipping traffic, as evidenced by our modelling of the detection areas of the PAM stations. The stations close to the St. Lawrence Seaway shipping route had only $10 \%$ of the detection capacity of the other distant stations. Although the Old Harry and Cabot stations had comparable detection areas and distances to the main traffic lane, only the former station had detections, when both stations were on duty between November 2010 and February 2013. The absence of detection in Belle Isle Strait, where the traffic is several times lower than in St. Lawrence Seaway (Simard et al. 2014), may be related to the low PAM effort (only 1 year, in 2010-2011), realized during a period when detections in the southern Gulf of St. Lawrence were low. The narrow width of the strait would have constrained the whales within detection range of the recorder, even in the unlikely case of a detection area as low as Old Harry or Cabot stations. Further PAM effort is needed to document the actual occurrence of NARWs in this area.

Since most NARW detections were in the southern Gulf of St. Lawrence, the migration path with the Atlantic is through Cabot Strait rather than through Belle Isle Strait. The lack of detections at the Cabot Strait station may result from a too-distant migration path for detection, beyond the reach of the $10 \mathrm{~km}$ median detection range of this PAM station. This would be the case if the animals entering from the Atlantic tended to avoid the main outflow current of the Gulf, located in the southwest half cross-section of the $\sim 100 \mathrm{~km}$ wide strait, where the PAM station was located (Galbraith et al. 2017, their Figs. 67-69). An alternative possibility is that the animals were less vocal during travelling.

The absence of detections in the whale feeding ground at the head of the Laurentian channel in the Lower St. Lawrence Estuary, despite the long-term PAM effort at Les Escoumins station, does not support any notable use of this area by NARWs, although NARW sightings have been reported for this area on a few rare occasions.

\subsection{NARW up-call diel pattern}

We did not observe any strong diel cycle in NARW contact call detections in the regional topographic basin off Gaspé from June to January. More hours with NARW up-calls during daytime were observed near Emerald Bank on the Scotian Shelf, but this pattern was absent in the neighbouring Roseway Basin 
(Mellinger et al. 2007). In contrast, more NARW upcalls were detected around sunset and during the night in seasonal PAM series at Stellwagen Bank and Jeffreys Ledge on the eastern US coast (Mussoline et al. 2012). Such a pattern of increased detections at sunset was noted during the months of high vocal activity, from February to May, but was absent in the other months from a 3.5 yr PAM time series in Massachusetts Bay (Morano et al. 2012). A bimodal increase in the general up-call pattern, with a main peak from 13:00 to 20:00 $\mathrm{h}$ and a secondary peak from 04:00 to 08:00 $\mathrm{h}$, with considerable variability from month to month, was observed in a year-round PAM series in the central Gulf of Maine (Bort et al. 2015).

Speculations on the causes of these contrasting diel call patterns invoked the diel vertical migration (DVM) pattern of NARW zooplankton prey, prey abundance and lower calling activity during foraging, based on tagged whales (Parks et al. 2011). In areas where food was presumed less abundant, foraging was postulated to mainly occur during the night phase of zooplankton DVM, which would allow more time for social activity (hence calls) during the daytime (Mellinger et al. 2007). More contact calls around sunset were speculated to correspond to lower foraging activity due to more diffuse prey, allowing increased time for social and calling activities (Mussoline et al. 2012).

None of these explanations involving prey DVM, prey abundance and concentration, combined with lower NARW calling during foraging, could explain the absence of diel patterns in NARW calls in the Gulf of St. Lawrence. If such prey/foraging/calling relations exist, either the feeding activity or the prey availability and abundance are constant throughout the $24 \mathrm{~h}$ cycle in this ecosystem, with neither possibility being exclusive. The alternative is that the NARW calling activity is not time-structured in this region, nor is the call availability to the recorders due to caller detectability range, which is related to whale displacement relative to the PAM station.

Nevertheless, as stressed by the other studies, the problem of the time pattern of NARW up-calls is complex because of the large number of factors involved, combining the inherent variabilities of NARW calling, displacement and feeding behaviours, multiscale time-space distribution of prey and spatial detection probability. In any case, this complexity supports the need for sufficiently dense sampling around the clock to reduce the error and minimize the risk of bias in such PAM studies (Van Parijs et al. 2009).

\subsection{Long-term PAM over time and space}

As in several other studies, long-term PAM proved to be an invaluable tool to monitor whale distributional changes. However, the technique is not errorfree, and the interpretation of the results requires caution since (1) NARW calling behaviour is variable and dependent on the individual whale and its activity (Parks et al. 2011), (2) the detection area strongly depends on the 3-dimensional location of the recorder relative to call propagation paths, bathymetry and ambient noise, (3) detection depends on the efficiency of the automatic detector, and (4) detection also depends on the SNR characteristics of the instrument and its duty cycle. In this study, sources of variability were minimized by using the same instrument and detection algorithm at all stations, and the differences in detection areas among the stations were documented. The independence of the detection efficiency relative to the density of calls present in the recordings adds to the confidence that the reported call occurrences and presences reflect the actual NARW calling activity and not variability due to detection performance.

Acknowledgements. This work was funded by Fisheries and Oceans Canada (DFO), a Natural Science and Engineering Research Council of Canada (NSERC) Discovery grant to Y.S. and the DFO Research Chair in underwater acoustics applied to marine mammals and their ecosystem at ISMERUQAR. We thank all technicians and crews of the research vessels who contributed to preparation, deployment and retrieval of the instrumentation at sea. We are grateful to $M$. Scarratt for improving the English readability.

\section{LITERATURE CITED}

Aulanier F, Simard Y, Roy N, Bandet M, Gervaise C (2016a) Groundtruthed probabilistic shipping noise modeling and mapping: application to blue whale habitat in the Gulf of St. Lawrence. Fourth International Conference on the Effects of Noise on Aquatic Life, Dublin. Acoust Soc Am Proc Meetings Acoust 27, 070006, p 1-14

Aulanier F, Simard Y, Roy N, Gervaise C, Bandet M (2016b) Spatio-temporal exposure of blue whale habitats to shipping noise in St. Lawrence system. Res Doc 2016/090. DFO, Canadian Science Advisory Secretariat, Ottawa

Baumgartner MF, Mate BR (2003) Summertime foraging ecology of North Atlantic right whales. Mar Ecol Prog Ser 264:123-135

Baumgartner MF, Mussoline SE (2011) A generalized baleen whale call detection and classification system. J Acoust Soc Am 129:2889-2902

Baumgartner MF, Cole TVN, Campbell RG, Teegarden GJ, Durbin EG (2003a) Associations between North Atlantic right whales and their prey, Calanus finmarchicus, over diel and tidal time scales. Mar Ecol Prog Ser 264:155-166 
Baumgartner MF, Cole TVN, Clapham PJ, Mate BR (2003b) North Atlantic right whale habitat in the lower Bay of Fundy and on the SW Scotian Shelf during 1999-2001. Mar Ecol Prog Ser 264:137-154

Baumgartner MF, Wenzel FW, Lysiak NSJ, Patrician MR (2017) North Atlantic right whale foraging ecology and its role in human-caused mortality. Mar Ecol Prog Ser 581:165-181

Bort J, Van Parijs SM, Stevick PT, Summers E, Todd S (2015) North Atlantic right whale Eubalaena glacialis vocalization patterns in the central Gulf of Maine from October 2009 through October 2010. Endang Species Res 26:271-280

Clark CW (1982) The acoustic repertoire of the Southern right whale, a quantitative analysis. Anim Behav 30:1060-1071

Clark CW, Gillespie D, Nowacek D, Parks SE (2007) Listening to their world: acoustics for monitoring and protecting right whales in an urbanized world. In: Kraus SD, Rolland RM (eds) The urban whale. Harvard University Press, Cambridge, MA, p 333-357

Clark C, Ellison W, Hatch L, Merrick R, Van Parijs S, Wiley D (2011) An ocean observing system for large-scale monitoring and mapping of noise throughout the Stellwagen Bank National Marine Sanctuary. Reports to the National Oceanographic Partnership Program, Stellwagen project, Award number N00014-07-1-1029

Cole TVN, Hamilton P, Henry AG, Duley P, Pace RM III, White BM, Frasier T (2013) Evidence of a North Atlantic right whale Eubalaena glacialis mating ground. Endang Species Res 21:55-64

Collins MD (1993) A split-step Padé solution for the parabolic equation method. J Acoust Soc Am 93:1736-1742

Cooke JG (2018) Eubalaena glacialis. The IUCN Red List of Threatened Species 2018: e.T41712A50380891. http:// dx.doi.org/10.2305/IUCN.UK.2018-1.RLTS.T41712A503 80891.en

COSEWIC (Committee on the Status of Endangered Wildlife in Canada) (2013) COSEWIC assessment and status report on the North Atlantic right whale Eubalaena glacialis in Canada. Committee on the Status of Endangered Wildlife in Canada, Ottawa

Wavis GE, Baumgartner MF, Bonnell JM, Bell J and others (2017) Long-term passive acoustic recordings track the changing distribution of North Atlantic right whales (Eubalaena glacialis) from 2004 to 2014. Sci Rep 7:13460

DFO (Fisheries and Oceans Canada) (2014) Recovery strategy for the North Atlantic right whale (Eubalaena glacialis) in Atlantic Canadian waters [Final]. Species at Risk Act Recovery Strategy Series. DFO, Ottawa. www. registrelep.gc.ca/virtual_sara/files/plans/rs_bnan_narw_ am_0414_e.pdf

DFO (2018) Science advice on timing of the mandatory slowdown zone for shipping traffic in the Gulf of St. Lawrence to protect the North Atlantic right whale. Sci Rep 2017/042. DFO, Canadian Science Advisory Secretariat, Dartmouth. https://waves-vagues.dfo-mpo.gc.ca/Library/ 40659793.pdf

Galbraith PS, Chassé J, Caverhill C, Nicot P and others (2017) Physical oceanographic conditions in the Gulf of St. Lawrence in 2016. Res Doc. 2017/044 DFO, Canadian Science Advisory Secretariat. Ottawa. https://wavesvagues.dfo-mpo.gc.ca/Library/40613677.pdf

Gillespie D (2004) Detection and classification of right whale calls using an 'edge' detector operating on a smoothed spectrogram. Can Acoust 32:39-47

Greene CH (2016) North America's iconic marine species at risk due to unprecedented ocean warming. Oceanography 29:14-17

* Greene CH, Meyer-Gutbrod E, Monger BC, McGarry LP and others (2013) Remote climate forcing of decadalscale regime shifts in Northwest Atlantic shelf ecosystems. Limnol Oceanogr 58:803-816

G Grieve BD, Hare JA, Saba VS (2017) Projecting the effects of climate change on Calanus finmarchicus distribution within the U.S. Northeast Continental Shelf. Sci Rep 7:6264

Hayes SA, Gardner S, Garrison L, Henry A, Leandro L (2018a) North Atlantic right whales-evaluating their recovery challenges in 2018. NOAA Tech Memo NMFS-NE247. www.nefsc.noaa.gov/nefsc/publications/tm/tm247/ tm247.pdf

Hayes SA, Josephson E, Maze-Foley K, Rosel P and others (2018b) US Atlantic and Gulf of Mexico marine mammal stock assessments - 2017, 2nd edn. NOAA Tech Memo NMFS NE-245. www.nefsc.noaa.gov/publications/tm/ tm245/tm245.pdf

Jensen FB, Kuperman WA, Porter MB, Schmidt H (2011) Computational ocean acoustics, 2nd edn. Springer, New York, NY

Kraus SD, Rolland RM (eds) (2007a) The urban whale. Harvard University Press, Cambridge, MA

Kraus SD, Rolland RM (2007b) Right whales in the urban ocean. In: Kraus SD, Rolland RM (eds) The urban whale. Harvard University Press, Cambridge, MA, p 1-39

Kraus SD, Prescott JH, Knowlton AR, Stone GS (1986) Migration and calving of right whales (Eubalaena glacialis) in the western North Atlantic. In: Brownell RL, Best PB, Prescott JH (eds) Right whales: past and present status. IWC, Cambridge, p 139-144

Loring DH, Nota DJG (1973) Morphology and sediments of the Gulf of St. Lawrence. Bull Fish Res Bd Can, Vol. 182. Fisheries and Marine Service, Ottawa

Matthews JN, Brown S, Gillespie D, Johnson M and others (2001) Vocalisation rates of the North Atlantic right whale (Eubalaena glacialis). J Cetacean Res Manag 3:271-282

Mellinger DK (2004) A comparison of methods for detecting right whale calls. Can Acoust 32:55-65

* Mellinger DK, Nieukirk SL, Matsumoto H, Heimlich SL and others (2007) Seasonal occurrence of North Atlantic right whale (Eubalaena glacialis) vocalizations at two sites on the Scotian Shelf. Mar Mamm Sci 23:856-867

*Meyer-Gutbrod EL, Greene CH (2018) Uncertain recovery of the North Atlantic right whale in a changing ocean. Glob Change Biol 24:455-464

* Meyer-Gutbrod EL, Greene CH, Sullivan PJ, Pershing AJ (2015) Climate-associated changes in prey availability drive reproductive dynamics of the North Atlantic right whale population. Mar Ecol Prog Ser 535:243-258

Meyer-Gutbrod EL, Greene CH, Davies KTA (2018) Marine species range shifts necessitate advanced policy planning: the case of the North Atlantic right whale. Oceanography 31:19-33

Morano JL, Rice AN, Tielens JT, Estabrook BJ, Murray A, Roberts BL, Clark CW (2012) Acoustically detected yearround presence of right whales in an urbanized migration corridor. Conserv Biol 26:698-707

*Mouy X, Bahoura M, Simard Y (2009) Automatic recognition of fin and blue whale calls for real-time monitoring in the St. Lawrence. J Acoust Soc Am 126:2918-2928

* Mussoline SE, Risch D, Hatch LT, Weinrich MT and others (2012) Seasonal and diel variation in North Atlantic right whale up-calls: implications for management and con- 
servation in the northwestern Atlantic Ocean. Endang Species Res 17:17-26

OALIB (Ocean Acoustic Library) (2016) Ocean Acoustic Library, Acoustic Toolbox, RAMSsurf. http://oalib. hlsresearch.com/PE/index.html (accessed 3 Dec 2018)

Pace RM, Corkeron PJ, Kraus SD (2017) State-space mark-recapture estimates reveal a recent decline in abundance of North Atlantic right whales. Ecol Evol 7: 8730-8741

Parks SE, Tyack PL (2005) Sound production by North Atlantic right whales (Eubalaena glacialis) in surface active groups. J Acoust Soc Am 117:3297-3306

Parks SE, Urazghildiiev I, Clark CW (2009) Variability in ambient noise levels and call parameters of North Atlantic right whales in three habitat areas. J Acoust Soc Am 125:1230-1239

Parks SE, Searby A, Célérier A, Johnson MP, Nowacek DP, Tyack PL (2011) Sound production behavior of individual North Atlantic right whales: implications for passive acoustic monitoring. Endang Species Res 15:63-76

Perry JW, Kent A, Berry MM (1955) Machine literature searching X. Machine language; factors underlying its design and development. Am Doc 6:242-254

Pettis HM, Pace RMI, Hamilton PK (2018) North Atlantic Right Whale Consortium 2018 annual report card. Report to the North Atlantic Right Whale Consortium. www.narwc.org/uploads/1/1/6/6/116623219/2018report _cardfinal.pdf

Senneville S, Lefaivre D (2015) Reproduction horaire et à trois dimensions des conditions hydrographiques et hydrodynamiques du Golfe du Saint-Laurent avec le modèle MoGSL pour la période de 1997 à 2014. In: Fisheries and Oceans Canada MLI (ed) Rapport 2014-2015 de l'entente de contribution entre le MPO et l'ISMER/ UQAR pour la simulation numérique des océans. Unpublished Report, Mont-Joli

Simard Y (2009) Le Parc Marin Saguenay-Saint-Laurent: processus océanographiques à la base de ce site d'alimentation unique des baleines du Nord-Ouest Atlantique. The Saguenay-St. Lawrence Marine Park: oceanographic process at the basis of this unique forage site of Northwest Atlantic whales. Rev Sci Eau 22:177-197

Simard Y, Lavoie D (1999) The rich krill aggregation of the Saguenay - St. Lawrence Marine Park: hydroacoustic

Editorial responsibility: Rebecca Lewison,

San Diego, California, USA and geostatistical biomass estimates, structure, variability, and significance for whales. Can J Fish Aquat Sci 56: 1182-1197

Simard Y, Roy N (2008) Detection and localization of blue and fin whales from large-aperture autonomous hydrophone arrays: a case study from the St. Lawrence estuary. Can Acoust 36:104-110

Simard Y, Roy N, Giard S, Yayla M (2014) Canadian yearround shipping traffic atlas for 2013: Vol 1, East Coast marine waters. Can Tech Rep Fish Aquat Sci 3091:1327

* Simard Y, Roy N, Gervaise C, Giard S (2016) Analysis and modeling of 255 source levels of merchant ships from an acoustic observatory along St. Lawrence Seaway. J Acoust Soc Am 140:2002-2018

Širovi A, Hildebrand JA, Wiggins SM (2007) Blue and fin whale call source levels and propagation range in the Southern Ocean. J Acoust Soc Am 122:1208-1215

* Trygonis V, Gerstein E, Moir J, McCulloch S (2013) Vocalization characteristics of North Atlantic right whale surface active groups in the calving habitat, southeastern United States. J Acoust Soc Am 134:4518-4531

* Urazghildiiev IR, Clark CW (2006) Acoustic detection of North Atlantic right whale contact calls using the generalized likelihood ratio test. J Acoust Soc Am 120: 1956-1963

*Urazghildiiev IR, Clark CW (2007) Acoustic detection of North Atlantic right whale contact calls using spectrogram-based statistics. J Acoust Soc Am 122: 769-776

Urazghildiiev IR, Clark CW, Krein TP (2008) Detection and recognition of North Atlantic right whale contact calls in the presence of ambient noise. Can Acoust 36: 111-117

* Van Parijs SM, Clark CW, Sousa-Lima RS, Parks SE, Rankin S, Risch D, Van Opzeeland IC (2009) Management and research applications of real-time and archival passive acoustic sensors over varying temporal and spatial scales. Mar Ecol Prog Ser 395:21-36

* Wishner KF, Schoenherr JR, Beardsley R, Chen C (1995) Abundance, distribution and population structure of the copepod Calanus finmarchicus in a springtime right whale feeding area in the southwestern Gulf of Maine. Cont Shelf Res 15:475-507

Submitted: December 17, 2018; Accepted: October 29, 2019 Proofs received from author(s): November 25, 2019 